\title{
PUBLIC INTEREST LITIGATION FOR REFUGEES IN SOUTH AFRICA AND THE POTENTIAL FOR STRUCTURAL CHANGE
}

\author{
JEFF HANDMAKER*
}

\begin{abstract}
A decades-long social justice struggle that eventually displaced white minority rule in South Africa culminated in democratic elections in 1994. Following this historic transition from authoritarian rule to democracy, new issues came to the fore, including the rights of refugees and migrants. Civic actors in South Africa again became mobilised around this human rights and social justice issue through public interest litigation in the framework of South Africa's bold, new Constitution. At different moments, civic actors confronted the government to fulfil its national and international obligations towards refugees. This article will briefly explain the emergence of new civic actors and issues in post-1994 democratic South Africa, and then elaborate three theoretical propositions on civic-state interactions to try and hold governments accountable to their human rights obligations. Next, these propositions will be applied to concrete examples where administrative law is tested in the domain of refugee law and policies. The article will conclude by briefly considering the extent to which public interest litigation in the area of refugee law and policies can inform the future prospects of public interest litigation in general.
\end{abstract}

\section{INTRODUCTION}

In the 1950 s, civic society ${ }^{1}$ in South Africa became mobilised against racist laws that penetrated nearly every aspect of civic life. Public interest litigation became one of the more visible means to challenge these laws. ${ }^{2}$ Following South Africa's historic transition from authoritarian rule to democracy, other issues came to the fore, including the rights of refugees and migrants, freedom of information and access to basic services. Although South Africa had a long history of migration, it only began formally admitting asylum seek-

* Lecturer in Law, Human Rights and Development at the International Institute of Social Studies, Erasmus University; Honorary Research Fellow at the School of Law, University of the Witwatersrand. The author formerly worked in various positions, including project coordinator on refugee rights from 1996 to 2000, for the organisation Lawyers for Human Rights in South Africa. Gratitude is extended to Jackie Dugard, Peter Alexander, Ebrahim Fakir, Karin Arts and two anonymous reviewers, for critical feedback on earlier drafts.

1 In this article, the term 'civic society' is preferred to the more common term 'civil society', reflecting both the broad diversity of non-state perspectives, and an assumption that non-state actors need not always be 'civil'.

2 As explained by RL Abel Politics by Other Means: Law in the Struggle Against Apartheid 1980-1994 (1995), lawyers were engaged in the 1980s and 1990s in challenging many laws that were the product of the then government's apartheid policies that regulated many aspects of human behaviour on a racial basis, including the Group Areas Act (designating where one could live on the basis of race), the Immorality Act (which criminalised sexual interaction between races) and the Internal Security Act (which included various draconian provisions including the infamous s 29 or detention without trial). 
ers and recognising refugees in terms of internationally-recognised criteria from about 1994. The social justice challenges that refugees have faced in this period include access to asylum procedures, securing recognisable identification documents and obtaining access to social services. ${ }^{3}$

Cooperative efforts by civic actors to persuade the government to respond to these social justice challenges often succeeded. However, growing numbers of asylum seekers from 1996 onwards, coupled with increasing animosity between civic actors and the government, meant that public interest litigation remained as the only option. Civic actors in South Africa were reconstituted into new structures and became mobilised around this 'new' human rights and social justice issue in the framework of South Africa's bold, new Constitution. At different moments, therefore, civic actors became engaged either in working with government to develop a refugee policy, or in confronting the government to fulfil its national and international obligations towards refugees.

This article, which draws on a broader study, ${ }^{4}$ discusses the dynamics of civic-state interactions aimed at the state's obligations to promote, protect and fulfil human rights. Through the lens of refugee legal advocacy in South Africa, this article examines and explains the circumstances under which public interest litigation, as a form of confrontational civic-state interactions, can lead to structural change for refugees, and provides some reflections as to what these interactions can teach us about the potential of public interest litigation to realise rights in general.

\section{(a) Researching a personal experience}

Similar to other researcher-practitioners, ${ }^{5}$ to a considerable extent, my research on civic-state interactions in South Africa from 1996 onwards has been a personal experience. As a lawyer working for the South African nongovernmental organisation (NGO) Lawyers for Human Rights (LHR) from the early 1990s, I witnessed major legal changes and dramatic political shifts, but also a staggering social burden that the African National Congress (ANC)led South African government inherited when it came to power in 1994. No one working in such an environment could possibly claim to be neutral, and I was no exception. However, as any good lawyer ought to do, I always strove to develop arguments based on reliable, or at least objectively verifiable facts. I continued to work as a legal advocate, advisor and more recently lecturer in South Africa at different stages until the present day.

3 J Handmaker, L De la Hunt \& J Klaaren (eds) Advancing Refugee Protection in South Africa (2008).

4 J Handmaker Advocating for Accountability: Civic-State Interactions to Protect Refugees in South Africa (2009).

5 MF Belvedere 'Beyond Xenophobia: Contested Identities and the Politics of Refugees in Postapartheid South Africa' PHD dissertation, University of Minnesota (2006); J Dugard 'Civil Action and Legal Mobilisation: The Phiri Water Meters Case' in J Handmaker \& R Berkhout (eds) Mobilising Social Justice in South Africa: Perspectives from Researchers and Practitioners (2010) 73-99. 
My background as a practitioner has certainly shaped me as a researcher and I have sought to preserve the same ethical values and bring my own experiences to researching the process of refugee policy development and practice in South Africa, ${ }^{6}$ interactions between civic actors and the government in different forms of social justice advocacy ${ }^{7}$ and other areas. ${ }^{8}$ Undertaking research related to my earlier, personal involvement in certain events posed certain challenges and opportunities.

As a participant in the early stages of the development of a refugee rights policy in South Africa, and later as a researcher, I had exceptional access to the actors involved in framing a refugee policy and associated documentation. While I was not directly involved in the three cases I examine in this article, I did follow developments closely and knew personally the lawyers who were handling these cases, and occasionally the lawyers on both sides. Hence, there was a generally high level of trust and access among those I interviewed in order to develop the picture of discussions on refugee rights policy in South Africa that began to emerge in earnest from 1996 onwards. Like Florencia Belvedere, I believe strongly that my personal engagement in these issues has been of tremendous benefit to this study. At least, I felt I was able to make more informed decisions about what aspects of refugee rights advocacy in South Africa were, in general, of greatest social relevance.'

The disadvantages of having been engaged in the subject of my study as a participant - in the early stages of refugee policy development and implementation - are also important to note. Just as neutrality is difficult, if not impossible for any practitioner, academic objectivity for a researcher is particularly difficult where one has participated in some of the events being reflected upon. ${ }^{10}$ More specifically, there may be dual pressures on the researcher to take a position that is policy-relevant, while also meeting the very real needs of those who are the subject of the research. ${ }^{11}$ In short, while subjectivity may make one more sensitive to the topic being represented and the actors involved; inevitably it also leads one to make judgments.

Given this dilemma, I have avoided labelling the 'rightness' or 'wrongness' of certain approaches, but have attempted to explain their consequences instead. I have also made it clear to those I have interviewed that it was not

6 Handmaker et al (note 3 above); J Handmaker 'No Easy Walk: Advancing Refugee Protection in South Africa' (2001) 48(3) Africa Today 91; J Handmaker 'Who Determines Policy? Promoting the Right of Asylum in South Africa' (1999) 11 Int J of Refugee Law 290.

7 Handmaker \& Berkhout (note 5 above); Handmaker (note 4 above).

8 J Handmaker 'Beyond Exclusion: Assessing Palestinian Refugees' Struggle for Protection and Recognition and their Potential Contribution to a Peace Settlement' in K van der Borght (ed) Imagining a Shared Future: Perspectives on Law, Conflict and Economic Development in the Middle East (2011); J Handmaker 'Responsibility to Protect When International Authorities Fail', in S Asfaw, G Kerber \& P Weiderud (eds) The Responsibility to Protect: Ethical and Theological Reflections (2005) 70-82.

9 Belvedere (note 5 above) 22-6. Belvedere acknowledged that she was similarly involved in events she later analysed in her $\mathrm{PhD}$ thesis.

10 B Cooke \& U Kothari Participation: The New Tyranny? (2001).

11 K Jacobsen \& LB Landau 'The Dual Imperative in Refugee Research: Some Methodological and Ethical Considerations in Social Science Research on Forced Migration' (2003) 27 Disasters 185. 
my principal intention to be policy-relevant, although I hoped that the findings and conclusions I made could be of use to practitioners. Furthermore, I have based my observations and conclusions on South Africa's explicit normative commitments, as well as other written documentation, media reporting and semi-structured interviews.

\section{(b) Purposes of this article}

With the overall objective to theorise the relationship between civic actors and the government in the context of public interest litigation on refugees' rights, this article has four main sub-objectives. First, the article will briefly explain the emergence of new civic actors and issues in post-1994 democratic South Africa. Second, the article will elaborate three theoretical propositions, namely that civic actors possess capacity to hold states accountable, that structure matters in conditioning the possibilities for exercising civic agency and that civic actors mediate the relationship between global rules and locally-relevant expressions of those rules. These three theoretical propositions incorporate both socio-legal as well as structure-agency explanations, recognising that structure both shapes the conditions under which agency takes place, but can also change in ways that shape the possibilities for future civic-state interactions. Third, these propositions will be applied to concrete examples where administrative law is tested in the domain of refugee law and policies. Finally, the article will briefly consider the extent to which public interest litigation in the area of refugee law and policies can inform the future prospects of public interest litigation in general, and lead to structural changes in power relations.

\section{New Civic Structures / New Issues}

Civic structures that pursue social justice struggles in South Africa, and the new issues they confront, are essentially products of the late 1990s, although many of the strategies civic structures emulate were developed much earlier. ${ }^{12}$ As Richard Ballard and colleagues have explained, these new structures and issues were primarily defined by trade union opposition to the government's neo-liberal growth strategy, ${ }^{13}$ accompanied by spontaneous and eventually well-organised struggles against government failure to deliver basic services, including acts of direct resistance, civil disobedience or outright defiance of government policies.

According to Ballard et $\mathrm{al}^{14}$ the emergence of these new structures was mainly due to a dwindling of the South African liberation movement. This movement was widely regarded as the quintessential social movement of the

12 Handmaker (note 4 above) $75-8,82$.

13 This is known as the government's Growth, Employment and Redistribution (GEAR) strategy.

14 R Ballard, A Habib, I Valodia \& E Zuern 'Globalisation, Marginalization and Contemporary Social Movements in South Africa' (2005) 104 African Affairs 615; R Ballard, A Habib \& I Valodia (eds) Voices of Protest: Social Movements in Post-Apartheid South Africa (2006). 
20th century and principally represented by the ANC, although the ANC was by no means the only contributor. Ballard and his colleagues argued that this dwindling of the liberation movement was the result of various factors. Absorption of civic actors, who had formerly worked for civic organisations and NGOs, into the post-1994 government, meant there was limited institutional continuity. Furthermore, shifts from civic organisations to government led to profound changes in the political opportunity structure. This was accompanied by a growing trend of technocratic development. Despite the government's dramatically increased spending on welfare programmes, analysts such as Patrick Bond have rued the professionalisation of government departments, which has seen welfarism routinely trumped by pro-growth strategies. $^{15}$

Faced with a dwindling social movement, civic actors and government have been confronted with a range of issues they never previously dealt with to any serious degree, including access to government-provided basic services for all, access to HIV antiretroviral (ARV) drugs and refugees. ${ }^{16}$

Many major political, legal and institutional changes in the South Africa of the early 1990s - which also paved the way for a refugee policy - were the outcome of a political negotiations process. The Congress for a Democratic South Africa (CODESA), a broadly representative process including the then (recently unbanned) political movements, the nationalist-led government, and various representatives from civic organisations, was a principal vehicle for these negotiations. The agreements made during CODESA marked a major policy shift away from a colonial and authoritarian regime, based on ethnic divisions, to a democratic government established on the basis of universal franchise, accountability and social justice. ${ }^{17}$

This policy shift that ushered in South Africa's many democratic dispensations was therefore not only the product of formal negotiations between political movements and the white-minority government. It was the culmination of a long-fought political struggle involving multiple civic actors who had been mobilising for progressive change in an organised way, both within South Africa and at the international level, since at least the beginning of the 20th century. Policy shifts and the extended participation by civic actors in the political struggle in South Africa framed the conditions for public interest litigation, including efforts to protect the rights of refugees from the mid-1990s onwards. Human rights, and by extension refugee rights advocacy and litigation in South Africa have therefore been characterised not only by challenges to the existing legal normative framework, but by the pursuit of a strategy of 'correcting' the normative framework through reference to administrative law and international law and in particular the human rights corpus.

15 Ibid; P Bond Talk Left, Walk Right: South Africa's Frustrated Global Reforms (2006).

16 Ibid.

17 Of course, this is hardly uncontested. H Marais South Africa: Limits to Change The Political Economy of Transition (2001); Hein Marais, among others, has argued that the South African society, and especially its economy, has become dominated by powerful global corporations and the promotion of elite interests at the cost of the majority poor. 


\section{Theoretical Propositions}

Civic interactions to advocate state accountability for protecting refugee rights can be explained through three theoretical propositions, which I elaborate on in greater depth elsewhere, ${ }^{18}$ but will explain briefly in this part of the article. First, civic actors have the capacity to hold states accountable to their national and international legal obligations. Second, a conscious recognition of mainly state-based structural boundaries by civic actors is important, as they both condition the possibilities for civic agency and - through interactions with them - permit structural elaboration. Third, civic actors fulfil a central role in the translation of international rules in municipal legal contexts.

\section{(a) Civic capacity to hold states accountable}

The first theoretical proposition is that the capacity of civic actors to promote and, where possible, impose state accountability for meeting national and international legal obligations has been shaped by structural changes in relevant normative, global, regional and national legal frameworks, as well as by political developments. The context in which these developments have taken place is what Michael Ignatieff has termed a historically significant global human rights 'revolution', with juridical, advocacy and enforcement dimensions. $^{19}$

In addition to the introduction of numerous human rights instruments at the international level, changes have also occurred within the domestic legal systems of states, both in the industrialised global North and the newly-liberated global South, especially following the end of the Cold War. States have ratified Optional Protocols to international human rights treaties, which have, in the case of some countries such as South Africa, rendered these treaties directly enforceable in a country's national court system. These normative developments have been accompanied by a growing consciousness among civic actors, and especially lawyers, about the utility of drawing on international human rights obligations in domestic legal argumentation.

This human rights revolution, according to Ignatieff and others, ${ }^{20}$ has been groundbreaking for human rights advocates, as I have discussed elsewhere. ${ }^{21}$ As participants in international legal process, individuals and civic organisations have played key roles, from the framing of juridical standards to human rights enforcement, which have shifted the relationship between civic actors and the state. ${ }^{22}$

18 Handmaker (note 4 above) 19-58.

19 M Ignatieff (ed) Whose Universal Values? The Crisis in Human Rights (1999); M Ignatieff \& A Gutmann (eds) Human Rights as Politics and Idolatry (2001).

20 Ignatieff 1999 (note 19 above) 10-1; see also J Donnelly Universal Human Rights in Theory and Practice (2003); T Risse, SC Ropp \& K Sikkink The Power Of Human Rights: International Norms and Domestic Change (1999); W Korey NGOs and the Universal Declaration of Human Rights: 'A Curious Grapevine' (1998).

21 Handmaker (note 4 above) 28-36; R Higgins (ed) Problems and Process: International Law and How We Use It (1994).

22 Ibid. 
Civic participation in national legal process, and particularly the ability of civic actors to invoke national law and legal institutions, has also shifted the civic-state relationship, though by no means replaced it. ${ }^{23}$ The state and its structural institutions are still of primary significance. Civic legal interactions have affirmed the capacity of the courts to hold government accountable for carrying out its human rights obligations, thus negotiating a 'delicate balance' between court-sanctioned interventions and government decision-making through a careful interpretation of 'reasonableness' in government decisionmaking. ${ }^{24}$

\section{(b) Importance of structural boundaries}

The second theoretical proposition is based on a materialist approach, namely that boundaries that define the structural relationship between civic actors and the state shift in very specific ways that must be respected by civic actors (exercising their agency) if they want to be strategic in their efforts to hold states accountable. ${ }^{25}$ This understanding of the relationship between structure and agency, elaborated by sociologist Margaret Archer $^{26}$ as the 'morphogenetic approach', is an ideal method for explaining the dynamics of public interest litigation in South Africa. Such an approach recognises that government structures, which condition civic agency (at least in part), are the products of specific historical events. Structures are not, however, immutable. They may be elaborated through interplay with agency, by way of civic-state interactions.

Public interest litigation represents a confrontational expression of civic agency that is, generally speaking, more limited in scope than cooperative interactions (such as advising a policy-making process), but potentially has great value in elaborating a state-created structure. There are three variants of confrontational civic agency that aim to enforce government compliance. The first variant is legal review through internal administrative mechanisms and through the courts. The second variant of confrontational civic agency involves various efforts, often in conjunction with the media, aimed at publicly shaming the government for a particular act or omission. The third variant is essentially an extension of public shaming: mass mobilisation - openly confronting government through large-scale protest.

The specific forms of civic agency involved in public shaming and mass mobilisation include acts of civil disobedience, large-scale demonstrations, well-organised civic boycotts and other highly visible campaigns.

23 Handmaker (note 4 above) 36-41.

24 J Klaaren (ed) A Delicate Balance: The Place of the Judiciary in a Constitutional Democracy (2006); C Hoexter 'Standards of Review of Administrative Action: Review for Reasonableness' in Klaaren (2006) 63-4.

25 These boundaries include social, cultural and economic opportunities and inequalities, and in particular boundaries defined by race and class, although these are not comprehensively dealt with in this particular article.

26 MS Archer Realist Social Theory: The Morphogenetic Approach (2003). 
State institutions (primarily the courts, but also government institutions) may for various reasons define structural limitations to the expression of civic agency, and even suppress civic actors, particularly if they are confrontational. For example, police may refuse permission for a picket line, demonstrators may be arrested, and media portrayals of such interactions may be subject to government censorship. However, government efforts to suppress civic interventions may themselves be subject to civic legal challenge, leaving the courts to have the final say.

In countries that tend to have greater respect for the rule of law and relatively robust accountability mechanisms, such as South Africa, my research identified four principal structures - partly overlapping - that tend to condition confrontational forms of civic agency, including public interest litigation, to hold government accountable for realising its human rights obligations. These structures are the (1) administrative; and (2) legal structures responsible for administering a legal regime, such as the refugee legal regime; (3) democratic and constitutional monitoring structures; and (4) the structure of the media.

\section{(c) Civic actors as translators}

The third theoretical proposition draws from a socio-legal approach that civic actors fulfil a crucial role in mediating the translation of international legal norms into local contexts. This does not mean that those who are unfamiliar with international law and institutions are not in a position to bring a claim against the government, but the consciousness of these translators has undoubtedly been a powerful force in reinforcing social justice claims, and in particular legal claims, especially from the 1980 s onwards. ${ }^{27}$ In order to be effective translators, civic actors know, or ought to know, the complex social, economic and cultural circumstances in which rights become articulated and claimed. In other words, they must possess a 'double consciousness' of the content of international law and the circumstances in which it is enforced as well as the local/national context in which these international norms find expression. $^{28}$

The social distance between a civic actor (for example, a public interest NGO) and the state (for example, a government department that is the object of public interest litigation) can narrow or widen at any particular moment and is not in and of itself an indication of effectiveness. However, consciousness of the degree of social distance that exists at any given moment can reveal the potential dangers as well as strategic opportunities for civic actors engaged in public interest litigation, on the basis of which a strategic assessment can be made of who and what issues to litigate against and above-all when to litigate (or not). To deepen this understanding of civic actors as translators and understand the underlying social and political underpinnings of public

27 See Abel (note 2 above).

28 SE Merry 'Transnational Human Rights and Local Activism: Mapping the Middle' (2006) 108 American Anthropologist 38; SE Merry Human Rights and Gender Violence: Translating International Law into Local Justice (2006). 
interest litigation, I apply the concept of social distance, which is a dimension of legal pluralism. ${ }^{29}$ Social distance represents the degree of 'externalisation' between the law maker (state) and law recipient (civic actor), as represented by divergences in (1) meanings or assumptions; (2) the social and economic interests of all stakeholders; and (3) political positions that they each, respectively hold.

These three theoretical propositions provide a basis for understanding the dynamics of public interest litigation or 'litigating for accountability', which in this article is confined to litigating the rights of refugees. In the next part of the article, efforts to obtain access to asylum procedures and access to employment are analysed.

\section{Litigating for Accountability to Protect Refugees}

Litigating for accountability of the government to protect refugees has involved a combination of legal and non-legal measures. The legal, administrative and other structures against which lawyers, as civic agents, have brought public interest litigation cases have, as mentioned, been products of specific historical events. By the same token, the events that have taken place have also framed the possibilities for a particular kind of civic intervention.

Case studies in this article focus on civic efforts to hold the South African government accountable through the courts, as opposed to other types of civic-state interactions, including policy formation or implementation. Since refugee procedures were formerly introduced into South Africa in 1993, two issues have come to the fore as being of particular significance to protecting the interests and rights of refugees, namely ensuring access to refugee status determination procedures and promoting access to economic and social rights, particularly the right to work.

\section{(a) Litigating access to status determination procedures}

Refugee status determination procedures in South Africa initially arose from a policy regime that for decades was geared entirely towards exclusion of so-called 'prohibited persons' or persons without legal residential status. ${ }^{30}$ As there was no provision for admittance on the basis of persecution or war, asylum seekers and refugees also fell into this prohibited persons category. Although concessions were made to admit refugees in the context of the old policy regime, it was not until the passing of a Refugees Act 130 of 1998, which came into force in April 2000, that asylum seekers had an explicit legal claim for protection. ${ }^{31}$

29 RL Kidder 'Towards an Integrated Theory of Imposed Law' in S Burman \& BE Harrell-Bond (eds) The Imposition of Law (1979) 289-305.

30 This was the terminology used in the notorious South African Aliens Control Act 190 of 1991.

31 J Klaaren, J Handmaker \& LA De la Hunt 'Talking a New Talk: A Legislative History of the Refugees Act 130 of 1998' in Handmaker et al (note 3 above) 47-60. 
However, faced with a rapidly increasing refugee case load as asylum seekers throughout the African continent and especially in southern Africa became aware of South Africa as a safe destination, the Department of Home Affairs (DHA) was reluctant to implement the Refugees Act. Hence, the DHA sought ways to limit the number of asylum seekers reaching its borders, through various interdiction measures. One such measure was a crude interpretation of a 'first country of asylum' principle, which assumed that asylum seekers entering South Africa through a land border would have had an opportunity to claim asylum in another country and should return to that country to have their claims heard. This 'principle', commonly invoked by countries in the European Union that share a partially-harmonised asylum system, provides that one should not be permitted to claim asylum in one country if another country could potentially have offered that claimant protection. ${ }^{32}$ The policy measure that the government introduced essentially refused entry to the vast majority of asylum seekers at the land borders and was firmly challenged by South African NGOs, and notably by LHR, culminating in the case of $L H R v$ Department of Home Affairs 2001. ${ }^{33}$

Having interacted with the South African government extensively in the formulation of the Refugees Act, trained officials and interacted with the DHA in many other respects, including on individual cases, LHR and other NGOs undertook great efforts to amicably resolve the matter of turning back asylum seekers at the border with the then director-general of Home Affairs Billy Masethla. LHR intervened through various departmental officials with whom it had a good working relationship. The department did not, however, respond positively to these efforts and the interaction turned from quiet appeals and diplomatic overtures to a media battle. The department publicly accused LHR lawyers of being 'peacetime heroes' while LHR criticised the government for violating its international obligations and stated protection commitments towards refugees. LHR meanwhile developed a good relationship with one daily newspaper in particular, Business Day. ${ }^{34}$

A formal legal claim was eventually also launched by LHR to judiciallyreview the measure interdicting asylum seekers at the border on the grounds that it was an unlawful measure that was ultra vires the Refugees Act. ${ }^{35}$ The launching of a legal claim heightened the tensions with the DHA, leading to furious statements by Masethla that the "LHR would make a "fool" of itself in court'. ${ }^{36}$ Eventually, however, the director-general backed down after Minister of Home Affairs Buthelezi, from a different political party in the Government of National Unit publicly berated him. A short time afterwards, the policy

32 See S Lavenex Safe Third Countries: Extending the EU Asylum and Immigration Policies to Central and Eastern Europe (1999).

33 Unreported case no 10783/2001 (High Court of South Africa, Transvaal Provincial Division 2001).

34 Belvedere (note 5 above) 189-91.

35 Confirmed in an interview by the author with Jacob van Garderen in Pretoria, 1 March 2011, who filed the court papers (the matter was eventually settled out of court).

36 F Chothia 'Heroes are Warned Over Asylum Challenge' Business Day (24 April 2001). 
was set aside. While full causality was clearly impossible to measure with any certainty, Buthelezi made very clear in his statements to the press that the department was embarrassed by the measure.

Although the LHR case was never decided by the South African court, it is still an excellent example of public interest litigation that utilised a skilful combination of legal and non-legal means to force a structural change in policy. In particular LHR combined its launching of a legal complaint with an intensive extra-legal campaign that was waged in the media. So what are the explanations for this structural change?

LHR had brought the legal action against the government by invoking South Africa's international legal obligations, fully aware that the DHA's interpretation of 'safe third country' was fundamentally flawed. LHR gathered this knowledge through academic literature and policy statements, but also through interactions with the local office of the United Nations High Commissioner for Refugees (UNHCR) and by attending meetings of the executive committee of UNHCR in Geneva. Having knowledge of the local situation, LHR was in a good position to translate its global knowledge into a solid legal argument. In terms of social distance, LHR and the DHA could not have been further apart in terms of their meanings, interests and political positions. Indeed the DHA and LHR were blatantly antagonistic to each other. The department, in particular had a vastly different interpretation of their international obligations in terms of reception at the border and an apparent desire to make initial entry into the country far more restrictive, all related to a broader political agenda to be publicly seen to be stemming the flow of asylum seekers entering the country. However, the latter category shifted once the minister became involved. So what led to this shift?

As mentioned, LHR not only constructed a robust legal argument; the organisation also interacted closely with the media structure, and particularly a sympathetic journalist at the influential Business Day. LHR was clearly aware that internal tensions existed within the DHA between the minister and the director-general and these tensions played a decisive role in forcing Masethla to capitulate. As Buthelezi confirmed in the media, South Africa's international reputation was at stake as people were systematically being turned back at the border. In short, LHR recognised these structurally conditioning factors and planned its strategy accordingly. ${ }^{37}$

A much more confrontational type of public interest litigation that emerged in the early 2000 s, addressed the situation of asylum seekers who were entitled to enter the country, but had not gained physical access to the refugee reception offices (RROs), where their claims were actually processed. ${ }^{38}$ Lawyers were also concerned that asylum seekers and refugees be provided access for

37 Ibid.

38 As more than one highly frustrated South African lawyer mentioned (in confidence) to me, the fact that lawyers had started with challenging the bureaucratic criteria for fair refugee status determination procedures in 1996 and ended up, several years later, merely challenging access to the offices, represented a 'backward slide' in the behaviour of the DHA towards refugees and asylum seekers in South Africa. 
the purposes of renewing or extending their residence permits. Coupled with this was the temporary closure of DHA's office in Johannesburg - the largest RRO in the country - for a lengthy period in April 2005, and the introduction by officials in another RRO of a daily quota system that limited the physical number of applicants into the building. The end result was that thousands of asylum seekers were being denied access to the RROs, either to have their applications for refugee status considered or even to have their permits renewed. Without any proof of formal status, asylum seekers without permits were especially vulnerable to arrest and exploitation. ${ }^{39}$

Once again, after numerous, and ultimately unproductive exchanges between civic actors and the DHA, LHR launched court challenges in April and October 2005, insisting that the DHA improve its access to the RROs. Meanwhile, the Cape Town office of the Legal Resources Centre launched its own Court challenge with regard to similar policies in place at the RRO there, in the case of Kiliko $v$ Minister of Home Affairs. ${ }^{40}$ The Kiliko case concerned a policy in terms of which DHA officials were ordered to process only 20 asylum seeker permits per day. This meant that dozens, if not hundreds of would-be applicants were turned away on a daily basis.

The DHA offered to settle the LHR case in 8 May 2005, which LHR accepted; and the settlement was confirmed by a Court order. The May Court order had little effect in improving access. According to LHR attorney, Fritz Gaerdes, who issued a press release, the situation became even worse in June 2005, when the DHA permanently closed its Johannesburg office in Rosettenville, forcing asylum seekers and refugees to use other DHA offices, in particular the office in Pretoria:

\footnotetext{
the High Court ordered the Department of Home Affairs to prepare and file a plan to facilitate all asylum applications by newly arrived asylum seekers. This plan required the Department to outline clear steps that it intended taking to solve the problems that asylum seekers experienced to access the asylum procedures ... Since June we have continually monitored the situation. What we saw was that the daily queues at the Pretoria refugee reception office were on average 250 persons long, whilst the Department on average only assisted 45 newly arrived asylum seekers daily. The longer queues were therefore not due to a greater influx of asylum seekers in South Africa but, in our observations, rather due to departmental inaction and inefficiency. ${ }^{4}$
}

The High Court issued a further order in the form of a structural interdict on 11 November 2005, which among other matters required the DHA to employ the services of 'an independent process engineer or other suitably qualified individual to investigate, assess and make recommendations to ensure that asylum seekers can immediately access the asylum application procedures' ${ }^{42}$ LHR expressed satisfaction with the judgment, and declared it would continue to monitor the situation.

39 Belvedere (note 5 above) 191-278.

402006 (4) SA 114 (C).

41 LHR 'Court Orders the Department of Home Affairs to Take Steps to Make the Asylum Procedures More Accessible' press release (2005).

42 Ibid. 
Judgment in the Kiliko matter was finally delivered on 16 January 2006 . The Court judged the conduct of the DHA to be inconsistent with the fundamental rights of illegal foreigners as embodied in the Constitution of the Republic of South Africa, 1996. Accordingly, the Court also ordered a comprehensive structural interdict requiring the DHA to report on its progress in improving access to the Cape Town refugee reception office.

\section{(b) Litigating the right to work for asylum seekers}

Another type of claim taken up by public interest lawyers advocating for refugees in South Africa was to protect refugees and asylum seekers' right to work and, by extension to challenge discriminatory practices against them vis-à-vis South African nationals. It should be noted that, while cases brought to challenge the government's restrictions on access to asylum determination procedures were largely brought on the sole initiative of the legal NGOs, cases on socio-economic rights tended to involve greater coordination and/or consultation with refugee and migrants' groups.

As mentioned, the 1998 Refugees Act only came into force through administrative regulations in April 2000, and included a prohibition for asylum seekers to work or study for the duration of the consideration of their applications, which according to the regulations was to last no more than six months. Inevitably, the procedure took longer for the vast majority of refugee applicants and so asylum seekers were left with no option than to work illegally, since there were no provisions for government assistance and the aid provided by NGOs and churches was minimal. In other words, the right to work for asylum seekers was a matter of survival.

The case that public interest lawyers brought to challenge this regulatory prohibition was Minister of Home Affairs $v$ Watchenuka in $2001 .^{43}$ In the years leading up to this case, journalists of various newspapers in South Africa reported on the extremely difficult conditions that asylum seekers and refugees faced in their daily struggles for survival. ${ }^{44}$ This was at least an indirect result of an intensive, multi-year training programme for journalists by the Roll Back Xenophobia Campaign, which was very active in this period, following the launch of the Braamfontein Statement in $1998 .^{45}$

The Supreme Court of Appeals (SCA) eventually decided the Watchenuka case. The SCA declared the policy denying asylum seekers the right to work and study to be unlawful on the grounds that it violated the conditions for having a dignified life. The Court ordered the DHA's Standing Committee to consider the circumstances of each applicant when deciding on the prohibition on work and study, whether on a case-by-case basis or by formulating guide-

432004 (4) SA 326 (SCA).

44 '4,500 Illegal Held at the Borders' The Citizen (14 February 1998) 16; 'Illegal Rampages by Home Affairs' Mail\&Guardian (15 May 1998) 7; 'Solving the Refugee Problems' The Daily News (27 April 1998) 6; 'Spelling Relief for Rulani’s Refugees' Cape Argus (14 April 1998) 5.

45 Roll Back Xenophobia Campaign 'Braamfontein Statement: Racism and Xenophobia, A Violation of Human Rights' (1998). 
lines to be applied by RROs. Since individual screening would have entailed impossible administrative burdens, the prohibition was set aside.

While ensuring the right of asylum seekers to work was a success, albeit after nearly four years of litigation, challenging discrimination in employment practices was far more challenging. This applied in particular to the security industry, which was one of the few sectors in which many asylum seekers could find employment. The security industry in South Africa is partially privatised. It is overseen by a public-private entity known as the Security Officers Board. The Board had ruled that formal security jobs should be reserved for citizens only, meaning that refugees and asylum seekers employed in these jobs were in contravention of the law, which led LHR, refugee-led organisations such as the Union of Refugee Women and other civic organisations to try and settle the matter amicably by urging the Board to voluntarily lift the prohibition against asylum seekers and refugees. These efforts failed and a case was brought by the Union of Refugee Women, a refugee-led organisation, in close collaboration with LHR. ${ }^{46}$

The media also became very interested in the matter. Pretoria News reported that 'the Security Industry Act, which regulates the security industry does not unfairly discriminate against refugees and it is thus not in conflict with the Constitution'. ${ }^{47}$ Human rights lawyers representing the Union of Refugee Women, who brought the case against the Board, were frustrated to face a very experienced and noted human rights lawyer, Wim Trengove, as their opponent in Court. In explaining the Board's position, which departed from the conventional position of legal advocates not to comment on their client's cases, Trengove put forward his argument to the press:

that while the Act did favour citizens and permanent residents over non-citizens, it was not discriminatory. The mere fact that refugees had to comply with the Act did not mean they could not seek employment in other industries ... The security service industry was highly sensitive ... and extreme caution was required to ensure only trustworthy persons were permitted to become members. There was thus a need for strict and proper control. ${ }^{48}$

The case eventually ended up in the Constitutional Court, and it is worth elaborating on the legal reasoning by the justices, who were split on the matter. The reasoning by Justice Sachs, which as in so many of his eloquent judgments tried to find a middle ground, made extensive reference to South Africa's obligations in international law, the 'significance' of the Refugees Act, the 'historical and social setting in which the rights and entitlements of refugees have to be determined' and finally the 'constitutionally-mandated obligation to counteract xenophobia'. ${ }^{49}$ Justice Sachs referred to South Africa's traditional culture of hospitality; as well as the special reasons why refugees found themselves in the country being the consequence of 'instability and

47 Z Venter 'Security Industry Act Does Not Discriminate' Pretoria News (27 May 2006) 3.

48 Ibid.

49 Union of Refugee Women (note 46 above) paras 133-44. 
bloodshed in their home countries (that had) rendered life there intolerable'. ${ }^{50}$ However, ultimately Justice Sachs agreed with the leading judgment by Justice Kondile that the discriminatory measure was not unconstitutional since there was still the possibility of granting an exemption:

I see no reason why access to employment in the security industry by persons in their situation should not be permitted in relation to sectors such as these, where no high security interests are at stake. To bar them would be to discriminate against them unfairly. At the same time I would not regard it as unfair to keep them from guarding installations and persons where particularly high security considerations come into play. ${ }^{51}$

And so, the discriminatory measure remains, despite this somewhat contradictory reasoning. Although in both the Security Officers Board and Watchenuka cases the social distance remained very wide in terms of the meanings, interests and political positions held by civic actors and the government, the results were very different. A high-level Court decided both cases, and international obligations were invoked to insist that the government fulfil its protection obligations to refugees in this crucial area. LHR lawyer Jacob van Garderen argued that the media structure in this case 'may have been decisive', projecting a view that, while it may be reasonable to permit asylum seekers the right to work, this right had its limits, particularly in the highly sensitive area of security. ${ }^{52}$ While at the time Watchenuka was being heard, civic actors were actively engaged in interacting with the media, by the time the case against the Security Officers Board was brought, there was very little, if any training of the media taking place, and the South African media was notorious for its sensationalist reporting of crime and security. In other words, there was less attention paid to the media structure in challenging discrimination within the security industry as there was at the time asylum seekers were merely insisting on the right to work.

\section{(c) What kinds of structural changes took place?}

In response to these and other examples of public interest litigation, often in combination with non-legal measures as well, ${ }^{53}$ various structural changes have taken place. Furthermore, in all cases mentioned here, public interest lawyers not only creatively displayed their capacity to hold the government accountable in a variety of different cases, these lawyers actively fulfilled the role of translators, ensuring that the government's international obligations were an integral part of their legal argumentation.

Judgments were obtained, for example in the Watchenuka case, which ordered the government to change its regulatory prohibition against asylum

50 Ibid paras 145-6.

51 Ibid para 147.

52 Interview by the author with Jacob van Garderen in Pretoria, 1 March 2011.

53 It should be noted that, while the media was a regular and effective non-legal measure utilised by lawyers' groups such as LHR, broader advocacy campaigns during this period were limited and mostly low-key, generally confined to challenging xenophobia and promoting public awareness by projecting a positive image of asylum seekers and refugees as making contributions to South Africa. 
seekers being able to work. In other cases, judgments forced the government to take action, or to refrain from action. Cases have also been concluded by way of a consent order, whereby the government agrees to do (or not do) something, and the court formally confirms this.

A much more interesting type of judgment that has the potential to lead to structural change is the structural interdict, as ordered in Kiliko, which gave the government time to improve its behaviour and engaged civic actors, the court and government in a three-way relationship geared towards a lasting solution. In essence, while political positions and meanings may be very far apart, structural interdicts artificially narrow the social distance between civic actors and government through constructing a shared interest in a longterm solution. Here, it is essential to have a clear appreciation of the structural constraints faced by the government in order convincingly to argue that the government do things differently.

A final note to make is that litigation can be very productive, albeit hardly decisive, when combined with a skilful media campaign. ${ }^{54}$ This was certainly the case when LHR challenged the DHA's so-called 'third country policy', and was arguably also the case at the time the Watchenuka matter was heard.

\section{Conclusions - What Future Prospects for Public Interest LiTIGATION?}

So what can be concluded from this evaluation of public interest litigation to protect the rights and interests of refugees in South Africa? Furthermore, what implications do these conclusions hold for other issues, and in other geographical contexts?

First, it is crucial for civic organisations and individuals engaged in public interest litigation to not merely understand the law, but to appreciate the social, economic and political context in which interactions with the state take place; in other words, to make a socio-legal analysis. Consequently, a conscious appreciation of the social distance that always exists between civic actors and the government will reveal strategic challenges and opportunities throughout the course of public interest litigation. As the examples in this article reveal, civic actors are most certainly active participants in international and national legal processes and skilfully combine litigation with other forms of civic mobilisation, including interactions with the media.

Second, structural boundaries that condition civic actors' capacity to act (their agency) must be understood, and indeed critically assessed when making strategic choices. This includes not only the legal, administrative and constitutional structures, but also - and possibly more crucially - the media structure that plays such an important role in shaping public opinion, and potentially the views of the judges themselves.

54 See also the analysis by Dugard in this special issue, in relation to the Mazibuko and Joseph claims. 
Third, materialist explanations of public interest litigation can also be productive. Lawyers need to adopt what Archer has termed 'being human'; in other words, agency is not boundless and structure matters. Governmentprescribed structures shape, or at least condition, the possibilities for civic agency. The historically-specific conditions under which laws and policies were structured in the first place are, furthermore, deeply political. In addition, beyond the laws and the government agencies and courts interpreting these laws, there are other structural factors that potentially limit the scope for public interest litigation, not least the climate of public opinion that has held strong views regarding refugees and migrants.

This being said, expressions of civic agency that wield public interest litigation in order to try and hold states accountable do hold possibilities in what I have termed a narrow but significant space. ${ }^{55}$ The space is narrow in terms of it being heavily framed by state interests, but also significant in terms of the potential it can have for precipitating progressive structural changes.

Based on this analysis of public interest litigation to promote and protect refugee rights, it seems evident that more sophisticated explanations of the strategic calculation taken by civic actors are needed, as opposed to bland, donor-led, impact-oriented analyses that explain nothing of the context in which such cases were brought and even less about why such cases were brought in the first place. ${ }^{56}$ The supposed value of public interest litigation cannot be boiled down to an anecdotal list of 'success factors' that will be of little use to future litigation. In other words, it is crucial from a knowledgebuilding perspective to make more critical evaluations of the opportunities and constraints faced in securing structural change through public interest litigation.

South Africa continues to provide inspiring examples of public interest litigation, and provides much empirical material to critically explain the dynamics of public interest litigation, and inform practitioners on the potential of litigation to deliver structural change. An ongoing struggle for social justice, through public interest litigation, which was forged in South Africa's anti-apartheid struggle, is most certainly far from over. As researcher/practitioner Dugard writes in the context of the Mazibuko case, which ultimately failed in the Constitutional Court:

judicial defeat has neither deterred the campaign nor discouraged further uptake of proactive litigation ... the Mazibuko rights-based mobilisation has already indirectly impacted, and continues to impact, broader struggles in South Africa. The full extent of this impact can only be determined by future research. ${ }^{57}$

55 Handmaker (note 4 above) 211.

56 G Marcus \& S Budlender 'A Strategic Evaluation of Public Interest Litigation in South Africa' $<$ http://www.atlanticphilanthropies.org/learning/strategic-evaluation-public-interest-litigationsouth-africa>; see also R Berkhout \& U Seela 'Stretching a Human Rights Approach in Search of Social Justice’ (2011) 13 (1) Dev Issues 9-10.

57 Dugard (note 5 above) 95 . 